\title{
Syncretism in Māori Theology
}

Theology is God talk

A human attempt to

Theorise the Divine

Theology 'from here' and

Theology 'from elsewhere' (Darragh, 2003)

Theology is shaped by context (Tate, 2012)

Through indigenous eyes

Theology can be a platform

From which to rediscover, reclaim...

...reconcile and redefine our spirituality

In a neo-colonial context

As indigenous Māori Christians

Marsden and Ruatara preached

Jesus' blood mixed with whenua

And a new faith grew in the people

Māori prophets, as responses

To land lost, syncretised

Theologies, Māori and Christian

Innovative frameworks of faith

Developed in the face of devastation

Instilled in our people, a sense of hope

The plea of Māori messiahs all

Was to hold on to the land

To look courageously to the future 
Syncretism: a phenomenon where Indigenisation and Christianisation

Occur simultaneously (Jørgensen, 2013)

One where the power of those who control

Religion is disturbed and disrupted (Goosen, 2000)

Our prophets unsettled Pākehā power!

A deep-seated uncertainty of syncretism

Exists throughout Christian history (Jørgensen, 2013)

And yet the Church has always...

...been infused with local culture (Vilaça \& Wright, 2009)

Gods, spirits, rituals and ceremonies

Melt into one another

Akin to Christ's Mass and Solstice

Our traditions merged, like wearing black

Ringing bells, and blessing headstones

We embraced Christianity

Through the templates

Of our own knowledge (Cooper, 2017)

We 'did' Christianity our way

And we never fully abandoned

Our former spirituality (Lewis, Willing \& Mullan, 1995)

atua or Atua?

The Christians took our word

And offered it on the altar of the new God

A capitalised 'A' to signify

That 'the one true God' is superior

And a small 'a' to denote the 'lesser' (Tate, 2012).

"Māori indigenous theology is

Māori faith seeking Māori understanding.

It is theology developed by Māori for Māori” (Tate, 2012, p. 21)

"Māori theology is

Ranginui e tū nei,

Papatūānuku e takoto nei” (W. Te Haara, personal communication) 
Māori theology determines

The parameters of our spiritual reality

Where Hinenuitepō and Jesus embrace

Māori theology is atuatanga

Atuatanga is Māori spirituality

Atuatanga is all things atua 


\section{References}

Cooper, G. (2017). Gods and Kaupapa Māori research. In T. Hoskins \& A. Jones, Critical conversations in Kaupapa Māori, pp. 147-159. Wellington, New Zealand: Huia.

Darragh, N. (2003). Contextual method in theology: Learnings from the case of Aotearoa New Zealand. Pacifica: Australasian Theology Studies, 16(1), pp. 45-66.

Goosen, G. (2000). Syncretism and the development of doctrine. Colloquium, 32(2), 137-150.

Jørgensen, J. A. (2013). Indigenization, syncretism and the assumed boundedness of Christianity: A critique. In A. Adogame \& S. Shankar (Eds.), Religion on the move! New dynamics of religious expansion in a globalizing world (pp. 99-111). Leiden, Netherlands: Koninklijke Brill NV.

Lewis, J. J., Willing, L. V. \& Mullan, D. S. (1995). Koru and covenant: Reflections on Hebrew and Māori spirituality in Aotearoa. Orewa, New Zealand: ColCom Press.

Tate, H. (2012). He puna iti i te ao mārama: A little spring in the world of light. Auckland, New Zealand: Libro.

Vilaça, A. \& Wright, R. M. (Eds.). (2009). Native Christians: Modes and effects of Christianity among indigenous peoples of the Americas. Surrey, England \& Burlington, VT: Ashgate. 